Article

\title{
The Demands of Niqabi Women in the Telegram Subaltern Corner Orgullo Niqabi
}

\author{
Alexandra Ainz-Galende * and Rubén Rodríguez-Puertas \\ Department of Geography, History and Humanities, University of Almería, 04120 La Cañada, Spain; \\ E-Mails: aag486@ual.es (A.A.-G.), rubenrp@ual.es (R.R.-P.) \\ * Corresponding author
}

Submitted: 16 March 2020 | Accepted: 13 July 2020 | Published: 20 August 2020

\begin{abstract}
The present article is about Niqabi women belonging to the private Telegram instant messaging channel Orgullo Niqabi (Spanish for 'Niqabi Pride'). More specifically, our main objective is to explain what they are demanding, how they articulate their demands through that channel, and why they use it for communicating and to organize their actions. Said demands are mainly linked to their recognition as autonomous and political individuals within the different contexts in which they find themselves. First, our analysis will focus on categorizing their social and political demands for being recognized, not only as Muslims, but also as autonomous, independent, and political beings. Second, we intend to explain how those demands, expressed in the virtual world, are articulated in specific actions in the different societies and social contexts in which these women live. To this end, this article analyzes, following the procedures of the Grounded Theory, the discourses obtained through 27 in-depth interviews conducted in the first half of the year 2019. The strength of this research lies in overcoming the difficult access to these women and their discourses as well as in clarifying who they are, what they are demanding from the societies in which they live, how and why they are virtually grouped and the consequences of their virtual grouping in the different societies in which each of them lives.
\end{abstract}

\section{Keywords}

digital mobilization; fundamentalism; Niqabi pride; Niqabi women; political individuals; Telegram

\section{Issue}

This article is part of the issue "Religious Minorities and Struggle for Recognition" edited by Christophe Monnot (University of Lausanne, Switzerland/University of Strasbourg, France) and Solange Lefebvre (University of Montreal, Canada).

(C) 2020 by the authors; licensee Cogitatio (Lisbon, Portugal). This article is licensed under a Creative Commons Attribution 4.0 International License (CC BY).

\section{Introduction}

Over the last years, we have witnessed the convergence of countless changes shaping the idiosyncrasies of people along with the essence of their bonds, due to the revolution of ICTs as well as to the liquid nature of our societies (Bauman, 2007; Castells, 2008; Žižek, 2003). In our societies we have gone from the prevalence of a completely analogical reality to that of a hybrid reality, where online and offline activities coexist in some kind of symbiosis that makes possible the emergence of new channels of communication that were inconceivable until now (Olmeda, 2014). Moreover, this has allowed people, collectives, and communities like that of
Niqabi women to find new places for association, vindication, and even fighting. This way, the discourses of a lot of these individuals that, until now, were being silenced and strategically distorted-as a result, among other matters, of what Thompson calls "mediated visibility" (Thompson, 2005)-have found their (previously unthinkable) place. Nancy Fraser talks about "subaltern counterpublics" to refer to parallel discursive spaces where members of subordinated social groups make up and circulate counter-discourses, which in turn allows them to formulate alternative interpretations of their identities, interests and needs (Fraser, 1997, p. 115). This could be the case of Niqabi women in Telegram, the latter acting as a refuge and a place for regrouping on the 
one hand, and as a base for spreading, planning, and organizing activities aimed at reaching broader audiences on the other (Fraser, 1997). Telegram is an instant messaging application similar to WhatsApp but with the particularity of featuring secret chats and using encrypted data. Messages are client-client encrypted, and they cannot be sent or downloaded again. In any case, as in other contexts linked to citizen participation, by using Telegram these women have taken advantage of the change ICTs have brought to the method of social participation, which until now was influenced by the institutions. In this new environment, the philosophy of 'do it yourself' prevails. Here, the individual can become a prosumer of information contents in an autonomous way without depending on mass media, mass-communication networks or political agendas (McLuhan \& Barrington, 1972; Toffler, 1980). In this respect, Howard Rheingold (2004) talks about "smart mobs" referring to those persons capable of acting together without knowing each other, similar to the concept of imagined communities categorized by Anderson (2006). Members of these groups cooperate in ways that would be inconceivable in the past without the novel information and communication systems we have today and which allow us, among many other things, to connect with other systems and even to other people's phones (Rheingold, 2004), which have become a highly efficient way of spreading and exchanging information, thanks to their portability.

Thus, our objective is the analysis of the discourses of Niqabi women, specifically in relation to the demands and vindications they express in Telegram and how they use this space to articulate them. To achieve this analytical purpose, we have used Grounded Theory, starting with general questions, not hypotheses. Some of the questions were: Who are these women? What do they demand from the societies in which they live? Why did they choose to communicate using Telegram? Do their grouping and demands have some impact on offline life? The characteristics or attributes (variables) of our study have therefore emerged from the analysis carried out. Thus, we want to stress that our discoveries and the development of the theory are not based on deductive reasoning supported by a previous theoretical framework (Charmaz, 1990), but following the aforementioned methodology.

In order for readers to fully comprehend the question we are addressing we will start talking about Telegram, the space where everything takes place. We will explain in detail every aspect of the proceeding, the methodology and the variables deduced from the analysis. This way, readers will have the whole picture of our questions and how we tried to answer them.

\section{Telegram as a Subaltern Corner}

Telegram may be used for a great variety of purposes (leisure, publicity, etc.). However, in the case of Orgullo Niqabi, it is used as a subaltern space whose main feature is to give room to the 'non-normative,' that is to say, to all kinds of users, without discrimination, groups which are not a majority or that are non-normative, subversive, and even of criminal or terrorist nature. These spaces are useful, among other things, for 'alternative' communication, that is, for giving voice to those individuals, groups, collectives, and even social movements of all kind that are silenced in life 'offline.' This allows them to put aside the 'marginalization' of the limited spaces where their voices could be heard. More specifically, Telegram channels are groups where people can send all kinds of contents: messages, pictures, links, files, etc. Channels may be public or private, and people can only access private channels if the creator of the group adds them or sends them an invitation to join. Channels are usually built around subjects and common interests shared by all of their users. A particularity of these channels is that messages are encrypted and can be 'destroyed' after a scheduled time without leaving a trace. It is precisely this peculiarity of Telegram which made Niqabi women choose this virtual space for creating their subaltern corner. On the one hand, it gives them the opportunity to freely express their interests and opinions and, on the other, whatever they say is kept private and far from the vigilance of their countries' state control mechanisms. That way, this space possess the double functionality of subaltern spaces: It functions both as a safe place for retreating and regrouping (that is why we call it a 'corner') and as the 'headquarters' for planning and organizing their actions. Moreover, it is in these subaltern spaces where alternative, divergent and subversive ideas are often presented, even ideas contrary to the hegemonic ones, in relation to the diversity of subjects, including identity (Downey \& Fenton, 2003). Thus, the goal of this article is to analyze and explain how, through one of these spaces - the subaltern corner we consider the community Orgullo Niqabi is in Telegram-women are grouped and organized, and how they articulate their political and social demands in order to go beyond the virtual world to the various realities to which they belong.

\section{Methodology}

\subsection{Participants}

The protagonists of our article are, as we have previously mentioned, Niqabi women. We call 'Niqabi women' those who, on the one hand, define themselves as Niqabi and, on the other hand, cover their face, hands, body, and feet, leaving uncovered only their eyes. However, these women associate the niqab not only to clothing, but to a form of behaving and living in the world that has to accompany said clothing and which is linked to a fundamentalist interpretation of Islam (Ainz, 2018). We understand fundamentalism as a religious way of thinking and acting which maintains that politics should be based on religious brotherhood. Its objective is to have societies once again centered around a religious order based 
on a holy book. In this regard, the holy book is considered full of sense and meaning, and it cannot be decomposed or freely interpreted by human reason. This way, divine law is declared superior to any form of society created by human beings. In the case of Islamic fundamentalism Roy (1992) identifies two trends within Islam: one representing part of the current Muslim movements, with a reformist style and not against modernity; the other (traditionalist) aiming to go back to the roots of Islam (the Quran and the Sunnah) and strictly and rigorously applying them to every sphere of society. According to Roy (1992), the former root defends an updated social and political model based on the precepts of the Islamic religion and criticizing traditionalism. The latter, which represents the women that participated in our study, rejects innovation and accepts the message from the past literally, which these women understand as ideal and still in force, accepting the validity of the founding texts and the prevalence of the Islamic law (the Sharia) over earthly, objective law. The origin of this second current lays, on the one hand, in what Roy (2010) calls "religious deculturation" and, on the other hand, in secularism. Religious deculturation takes place, essentially, by taking religion out of the public space. Secularism produces religion, says Roy (2010), who criticizes the presented solution, i.e., relegate religion to the private sphere. According to the author, the outcome of this solution is that a lot of believers respond with a will to reconquer the world they have lost.

With the aim of gathering and analyzing their identity, political and social demands, as well as understanding how Telegram is used as a space to gather said demands, we conducted 27 in-depth interviews with some of the members of the group Orgullo Niqabi.

Significant facts about these women, apart from those on Table 1 is that all of them say they are free and have willingly chosen the niqab, they all communicate in Spanish (some of them perfectly, others with some degree of difficulty), and they belong to various Islamic, Spanish-speaking online groups. In fact, it was in those groups that the idea of creating the Telegram channel first arose, a channel composed of Niqabi women from several Facebook and Telegram groups, and from Spanish-speaking forums. Attending to why they participate in this group, there are several parameters: (1) to intensify their practice of Islam; (2) to reassert their choice for the niqab; (3) to search the support and strength necessary to keep or start using the niqab; (4) to practice proselytism and encourage 'other sisters,' as they call it, to find that strength they search for choosing the niqab;

Table 1. Profiles of the interviewees (all names have been changed at the request of the women participating in the research).

\begin{tabular}{|c|c|c|c|c|}
\hline Name & Age & Residence & Nationality & Occupation \\
\hline Samia & 23 & Germany & Turkey & Housewife \\
\hline Dunia & 19 & Spain & Morocco & Unemployed \\
\hline Zyneb & 25 & Spain & Morocco & Housewife \\
\hline Fatin & 35 & Mexico & Tunisia & Housewife \\
\hline Sara & 34 & Mexico & Mexico & Housewife \\
\hline Sonia & 39 & Mexico & Mexico & Housewife \\
\hline Souad & 27 & Mexico & Mexico & Housewife \\
\hline Ikram & 41 & United States & Colombia & Housewife \\
\hline Meryem & 31 & United States & Colombia & Housewife \\
\hline Dunia & 31 & United States & Spain & Housewife \\
\hline Hakima & 32 & Romania & Romania & Housewife \\
\hline Salima & 28 & France & Algeria & Housewife \\
\hline Ahlam & 25 & France & Algeria & Housewife \\
\hline Fatima & 27 & Chile & Uruguay & Housewife \\
\hline Islam & 28 & Chile & Chile & Unemployed \\
\hline Romina & 27 & Venezuela & Venezuela & Housewife \\
\hline María & 35 & Venezuela & Morocco & Housewife \\
\hline Hanna & 35 & Venezuela & Turkey & Housewife \\
\hline Farida & 33 & Venezuela & Turkey & Housewife \\
\hline Yasmin & 25 & Venezuela & Syria & Unemployed \\
\hline Mery & 34 & United Kingdom & Iraq & Housewife \\
\hline Ratsida & 26 & United Kingdom & Algeria & Housewife \\
\hline Hafida & 33 & United Kingdom & Algeria & Housewife \\
\hline Melika & 29 & United Kingdom & Morocco & Housewife \\
\hline Nour & 36 & United Kingdom & Morocco & Housewife \\
\hline Amina & 25 & United Kingdom & Spain & Housewife \\
\hline Falak & 19 & United Kingdom & Spain & Unemployed \\
\hline
\end{tabular}


(5) to fight for their rights as Niqabi women. Regarding their main reason for being Niqabi, some of them have only spiritual or religious reasons, while others have also stated political reasons.

Concerning their educational level, five (5) women possess a basic level of education, 19 of them hold an intermediate level, and three (3) of them have a degree. Attending to their socialization in Islam, we find worth mentioning that there are 12 women who declare to "have turned to Islam," that is, they are converted. The rest were born and raised in Muslim families with different ways and intensities of living and practicing Islam. When asked if they were married-something of special interest when considering the converted ones-there are 14 women that are married, six (6) of them are converted. The rest is single. Attending to their jobs, some of them declare to be housewives and the rest unemployed. This is significant, since most of the housewives consider that women's work should be essentially tied to care in general and domestic care in particular. Thus, working outside home is for men. However, those who are unemployed do manifest that they would like to work, although their jobs should be halal (allowed) for women, mostly linked to care and to those spheres that theyand traditional patriarchal cultures-consider 'women's jobs.' We would like to stress that this study is somewhat peculiar, since these women's features are not representative of all Niqabi women around the world, which in some cases are forced to cover their bodies, and whose interpretation of the niqab, linked to subordination, is different.

\subsection{Procedure}

After years of continued online participation on several Spanish-speaking forums, groups, channels and social networks and their subsequent analysis (Ainz, Checa, \& González, 2011), as well as having participated in several Islamic communities and associations (Ainz, 2017) paying special attention to the discrimination that Muslim women suffered (Ainz, 2011), one of the authors of the present article was given the opportunity of joining the Telegram channel Orgullo Niqabi. Said channel, as we have pointed out, is composed of Niqabi women or women about to become Niqabi.

In order to conduct the 27 interviews, we used the program Skype, mainly for two reasons. The first is that many of the women interviewed resided outside Spain. The second and most important one has to do with the availability of the participants, who declared that, for various reasons, they preferred the interviews to be conducted that way. Regarding their reasons, it should be noted that many of them were closely linked to lack of time, the impossibility of reaching an agreement on the time and place of meeting, and the preference of using Skype since they could do the interviews at what they called their "free time." In fact, 19 out of the 27 women stated that if they did not do the interview via Skype it would be very difficult for them to participate in the study. With this reality on the table, we decided to fully adapt ourselves to what they considered appropriate in terms of how to conduct the interviews and the schedules they set. Taking into account that many of the participants reside in countries other than Spain, such as Mexico, the United States, Venezuela, Romania, France, Germany, Chile, and the United Kingdom, some of the interviews were conducted at untimely hours. We would like to point out that the interviews were conducted over six months, but in the lead up to these interviews preparatory work was carried out over approximately one and a half years with participants. This involved establishing contacts, building trust, and participating in many Islamic groups. Finally, our opportunity to participate in the Telegram group Orgullo Niqabi came, as we said, after our participation in different Islamic forums and a continuous interaction with the women subject of the study. It should be noted that it was not easy to earn their trust and conduct the interviews. One of the most active and interacting women, who is also the founder of the community, was the one who acted as a 'key,' making interviews possible. After much thought and after "doing salat istikhara" (a prayer consulting Allah) she considered a good idea to participate, arguing that it could be a good way of becoming visible. Thus, she encouraged women to participate by publishing an announcement on the Orgullo Niqabi channel. From that moment on, we could see a participatory spirit and attitude among the women. Specifically, 27 of the 143 women in the channel finally participated. Previously, there had been more of them that had expressed their interest, but finally, for various reasons, they did not participate in the study. The interviews were conducted in Spanish, and the quotes used in this text are translations made by the authors.

\subsection{Data Analysis Method}

In order to analyze the interviews we have used the procedures offered by the Grounded Theory (Glaser \& Strauss, 1967), which are related to the systematization of information and the development of analytical categorizations that show the most relevant patterns within the data. The Grounded Theory has its origin in the Chicago school of sociology and the development of symbolic interactionism at the beginning of the 20th century (Ritzer, 1993). Symbolic interactionism says that it is people who take part in society, individuals are considered social actors continuously shaping their environment (Cuff, Sharrock, \& Francis, 1990).

We used the program Atlas.Ti6 as encoding manager and for the creation of different codes on which the constant comparative method-which consists in analyzing the incidents contained within the data in order to find similarities and differences (Carrero, Soriano, \& Trinidad, 2012)-was applied. By doing so, we established four central categories. The first one, subaltern corner, refers to identity, political and/or social demands, as well as 
to the space and how these women use it to articulate said demands. The second category, the anger, is called that way based on the expression "it angers me that...," which a lot of these women used for expressing their discontent and argue their membership in the group Orgullo Niqabi. This is what in Grounded Theory is known as in vivo coding, that is to say, it is codified taking into account the expressions and literal language of the participants, given its relevance to the study. We understand that this 'common anger' that gives rise to the codification has a fundamental symbolic power which we will describe throughout the analysis. The third category, nodes, refers to what these women have described as a non-isolated individualization, that is, they say that they perceive their cultural, family and personal particularities individually within the group but, besides, they feel united by the niqab and everything around it, especially everything related to their discrimination, which all of them perceive in the same way. Finally, the fourth category, silent construction, refers to the social and political actions they plan and intend to transcend the virtual plane, carrying them out in their daily contexts, reinforced by their virtual grouping on Telegram and based on a strong group conscience.

\section{Results}

\subsection{Orgullo Niqabi: An Online, Subaltern Space}

Many silenced-or even marginalized-voices have found on the Internet, social networks, and instant messaging applications in general a space where they can be heard. In this particular case they have found it in one of the subaltern corners that Telegram offers. The Niqabi women under study claim to have found there what they call their community, Orgullo Niqabi, a space where they can express themselves freely, where they can share ideas in a horizontal communicative way, bypassing censorship and manipulation mechanisms, as stated by some of the interviewees when asked in which way did Orgullo Niqabi contribute to their lives:

I decided to become Niqabi, if one can really decide that. In fact, it is a command from Allah. The thing is that I found myself very alone. Even my Hijabi friends, you know, the ones that wear a veil, told me that I was very radical, they questioned me. There was a moment when I even doubted about my mental health. Finding this community of sisters in Telegram has made me very happy, it has brought me a lot of peace. I am very grateful to Allah for putting these sisters in my way. Here we are free, we say what we please, we express ourselves freely, we encourage each other in the way of Allah, in improving our practice. Thus, "our imam," our faith is much greater. We don't have to worry about giving explanations or continuously debunking myths about the niqab. (Samia, Germany)
Nobody understood me until I came here, I had no friends, everybody judged me in my environment, in my family....Society doesn't understand me, fine, but neither does my family and they are old-fashioned Muslims. The sisters in this community saved my life [laughs]. In Spain, people talk about freedom and democracy, but I find myself very limited. (Dunia, Spain)

When asked why they used Telegram and not other instant messaging applications, women participating in our study were very clear: they consistently referred to privacy, control, and vigilance. That is one of the main reasons why we talk about subaltern corner. Telegram is where these women feel somewhat safe to express themselves avoiding state control mechanisms. The fact that channels are private and require an invitation to join, and that messages can self-destroy, are the main factors why these women have found in Telegram their ideal place for meeting and expressing themselves:

Look, I am going to be clear. Here in Spain, I used to use Facebook. Muslims in general talked too much. There was a time when you could be arrested for nothing. There was this feeling that anything could be linked to terrorism. I'm not talking about Niqabi women, but almost anything you would do....I don't know how to explain it, anything... religious? Anything could be misunderstood and you could end up in jail. (Dunia, Spain)

Sometimes you were comfortably discussing on a Muslim group in Facebook, knowing some brothers and sisters, and the group was suddenly dismantled. Overnight, just like that. Then you knew from rumors that someone had been investigated, they had been reading our messages, who knows? You didn't even know who you were talking to, do you understand? You didn't know if people next to you were sisters, brothers, the police...that was a problem. It does not happen in Telegram. We know who we are inviting to the group, who is in, who is not....Telegram allows you to be more selective and feel safer. It allows you to say whatever you want, always within the parameters allowed by the Quran and the Sunnah, of course! It's not necessary even to give your phone number, when you are fed up or something you can simply say goodbye. (Amina, United Kingdom)

Finding a safe space was followed by organization: Derived from the opportunity to express themselves freely, these women were starting to draw up a manifesto called Manifiesto Niqabi when the interviews were conducted. There, they were gathering their impressions about the discrimination they perceive in their lives and expressing their identity, social and political demands. In this regard, two of the women declared: 
The main fact we are expressing there is that we are not submissive, that being Niqabi is something voluntary. We do it not as an order from our husbands, I'm not married. Neither it is from our parents. Our parents have nothing to do either. My father passed away, and I think he would be totally against it, he was a very modern man. I was very modern as well, I have danced, I have been topless, I have had sex, I have gone to the disco, may Allah forgive me. Luckily, I saw the right path. What we currently want is to let people know that we are free, nobody is forcing us in our countries, either. A lot of us are against how some women are forced, we understand that is not Islam. Islam is not force, it is passion. The niqab has to be well explained for women to be able to open their eyes. (Zyneb, Spain)

I laugh when somebody thinks that we are poor girls, that we are dumb and forced. People talk about us without knowing anything. That's the goal of the manifest: It's for people to know that there is a brain under the cloth and that because there is a brain, there is a cloth. (Fatin, Mexico)

\subsection{The Anger}

Tang and Yang (2011) pointed out in one of their texts that it is somewhat of a fallacy to believe that the Internet, throughout its several social networks, browsers and phone applications distributes symbolic power among ordinary people. They point out that it would be better to say that "the internet offers ordinary people the potential of this power" (Tang \& Yang, 2011, p. 677). In turn, Thompson defines symbolic power as the "capacity to intervene in the course of events, to influence the actions of others and indeed to create events, by means of the production and transmission of symbolic forms" (Thompson, 2005 , p. 19). Moreover, he says that it could materialize in interpreting others' symbols, creating opinion about others, etc. This power comes from the production, transmission and interpretation of "significant symbolic forms" (Thompson, 2005, p. 19). The author also points to religious, educational or media institutions as paradigmatic institutions of this type of power (Thompson, 2005, p. 34). The women under study express through their discourses their disagreement with some misconceptions that our societies have about them. Some examples are associating Islam to Arab territories and generalizing about Islam even though there are a lot of different schools, branches, and interpretations of this religion. These ideas are clearly reflected in the following paragraphs:

The fact that people think that we are what we are not makes me feel frustrated and angry. They define you, they tag you and then to top it, they discriminate you because of what they suppose you are. I wanted to go to the beach this summer, with what the media call burkini, and there I went. Not alone, because I am afraid of being jeered. I went with some friends. That's another story: to get your Muslim (Muslim!) friends to go to the beach with you. "Get out of here!" people said. I mean, first they tag you as submissive (you are "forced"), but then they are the ones that don't let you swim. They discriminate you. Somebody explain [this] to me, please. (Sara, Mexico)

The other day, I went to a shop to see some clothes. It was completely a show, a real show, because people look at me wherever I go. I was leaving the shop and I heard: "Go back to your country!" "But miss," I replied, "I am from here, from Guadalajara itself. I am more Mexican than a taco!" They don't realize that one doesn't need to be an Arab in order to be Muslim. One thing is the Din, the religion, as you call it, and other is your origin. (Sonia, Mexico)

I know that mass media are very harmful. They show Iranian women, which are not even Sunni, or women from Saudi Arabia or Afghanistan wearing a burqa and they say: "They are being forced, they are being forced." Well, you know? Some of them are forced, and I don't like that, but some are probably not forced, as is our case, and they can follow the path of Islam with all the love in the world. (Islam, Chile)

Castells (2009), in turn, introduces in this regard the emotion of 'anger' as a possible response to these circumstances, and that is why we decided to name this section so. It is well known that, with the Internet in general and with social networks and instant messaging applications in particular, everyone can share their ideas, perceptions, interests and, indeed, their frustration and anger, with a greatly broad audience. One of the issues that angers these women the most is, as we have seen, the inadequacy, the lack of correlation between what they claim to be and their perception of what the society interprets they are. Castells says in this regard that "if rage is indeed a purely individual feeling, the SMS will harmlessly drift in the ocean of digital communication. But if many people open the bottle thrown into the ocean, the genie will come out and an insurgent community will grow through the connection of different minds beyond the lonely revolt" (Castells, 2009, p. 473). All of this can be seen in the following extracts:

Here we were almost all of us online some minutes ago, talking, thinking about how to manage and what to do with these feelings that upset us so much. We are very active, you know? We have been very active in social networks, especially in Facebook, helping some sisters that wanted to start using the niqab, which had doubts or suffered just for wearing it or for wanting to do it but not being able to do so, due to their fears. But that's enough, we are many, we have to organize, make ourselves visible for who we really are and take action. (Sara, Mexico) 
May Allah forgive me, I speak frankly, sometimes I feel hate, because we are not allowed to spread out, but you see, people here are starting to become aware. We, the Mexican sisters, along with the mosque, do a very important job of inviting to Islam. But we must do more, not only as sisters, not only as Muslims, but as Niqabi, because even Muslim sisters, yes, that's right, what you hear, they discriminate us for being Niqabi. I was Christian, and God said "turn the other cheek," but Islam, subhana Allah [praised be Allah], says nothing like that, and we are fed up with being seen as fools. (Ikram, United States)

Sometimes I end up frustrated and fed up. It angers me! People don't understand or accept us, and they don't want to. Sometimes I think that it would have been better to have been born in a Muslim country, with your whole family being Muslim, within a context more akin to my way of feeling and living my life. But I live here and I was born in this family, alhamdulilah [thanks Allah]. The good thing is that I can be an example to others, I can help other sisters with the same problem and I can be by their side so they don't feel alone. (Souad, Mexico)

\subsection{The Nodes}

The Internet in general and Telegram in particular are useful not only for certain groups to communicate, as is the case of Niqabi women, but it is also a platform to carry out actions that allow, in turn, what could be defined as 'non-isolated individualization': being alone 'in person,' but being connected to something bigger that transcends the physical world; the network, the virtual world, the community. Being a node within a network implies a peculiar perception and participation that we can see reflected in the different arguments these women give:

Orgullo Niqabi has brought us together as sisters but, moreover, it has given us our faith in the community, our Umma, back. It's incredible how we can feel so close being so far. It's a feeling I cannot explain. I can spend weeks without talking to my parents, but I can't spend even half an afternoon without talking to my sisters. In the beginning, when we were knowing each other, I thought "how different we are!" I couldn't believe it! But in the end that difference has enriched us all, it has made us to learn from each other. Allah is great. Who would have told me that I would find this great support on the phone? I was very critical with mobile phones! (Meryem, United States)

According to Castells (2009), two cultural patterns converge in networks: individualism and communalism. On the one hand, users browse the Internet in the solitude of their persons with all their cultural and personal particularities, in front of their computers' or their mobile phones' screens; and on the other hand, they tend to form 'communities in practice,' that is, groups of individuals who share interests, values and beliefs. This can be clearly seen in the statements of some of the Niqabi women:

Look, no. We are a lot of sisters, in this group. All of us Niqabi, but all of us well different. We all have in common our love to Allah; we all have in common the Salat, the prayer, five times a day; we all have in common the Ramadan. But look little lady, some of us like blond men, others like dark-haired ones; some of us cook couscous, others cook tacos; some of us have lived in an Arab or Muslim country, others haven't seen Syria even in television. Some of us have, you know, some of us have a Muslim family and others have turned to Islam right now, some years or even months ago. What we have in common is Islam, the niqab, and now the group of sisters Orgullo Niqabi and our faith in carrying out a joint Project that is yet to be outlined. (Dunia, United States)

I have my own life. I grew up listening to Bob Marley because my brother likes his music a lot, he was somewhat a stoner [laughs], may Allah forgive me, may Allah guide him. Some sisters have never listened reggae, it scares them. Some sisters say that they have voted right-wing parties in the past, but I consider myself a left-wing person. The more to the left, the better. Here in Spain, left-wing politicians are the ones helping us. They are the ones that will let us enter the scene and be heard, I think. (Dunia, Spain)

\subsection{Silent Construction}

We could say that these women have constructed around the community Orgullo Niqabi a series of discourses and practices typical of what could be called 'symbolic community.' This particular community, located in cyberspace, with no apparent physical reference, presents liminal characteristics which, on the one hand, reflect the common significance that the actions these women carry out have for them and, on the other hand, transform them and create new ones. The "community Orgullo Niqabi," as these women call it, has not been limited or focused only in allowing them to express what they experience or how they feel with respect to their experience but, besides, the channel has been articulated as the basis for clearly planned future actions:

Meeting us on the private channel in Facebook was the beginning and creating the WhatsApp group was the second step. From there we migrated to Telegram, and here we have gained strength and confidence. We are many and we want to associate internationally, to create something big, hence the elaboration of the manifesto. We want to come to light and be heard and be able to participate in the social life that we are denied wherever we live. (Hakima, Romania) 
I don't know if you know what dawa is, if not, I tell you, it is an invitation to Islam. Well, that's what we want, to be active with this, spreading the message. Just imagine, we are a lot of sisters here. If each of us shows the path or makes the path easier to other two sisters, just imagine that! By now, that is our little big purpose, our project: To make women turn to Islam; Christian ones, Jews, atheists, everyone! We coordinate ourselves in the group for that, too. (Salima, France)

When asked if their project is part of-or responds tosome kind of institution, organization, mosque or something similar, these women answer "no," they say they are "independent." Moreover, they point out that, although it is true that they openly consider themselves Salafists, it is also true that, according to their discourses, behind the Niqabi group there is only faith for Allah and the attempt to spread what they consider "true Islam." When asked about this matter, they tell us about a fundamentalist Islam where private life is intended not to be separated from political life, where people are intended to practice as many of the Prophet's teachings as possible, and where the Quran is interpreted and followed literally. The latter characteristics are those that authors such as Pace and Guolo (2006) attribute to fundamentalism:

We don't follow anyone, I mean, we don't have any organization or political party behind. It is true that many of us like Muslim Brotherhood, but there are some sisters that don't even know what that is. As I've told you, we are very different people. The only thing we have in common is our imam, our faith in Allah, in our Prophet, and that we all feel Niqabi. (Ahlam, France)

Yes, I am Salafist, but Salafism is not terrorism. People are completely wrong. Salafism is the pure essence of Islam, the true practice of Islam carried out by our ancestors, the companions of the Prophet. It is practicing Islam without worrying about anything or anyone except Allah. I don't like terrorism, Allah doesn't order that, but he does order us to be strict in our practice, and that's why I am Niqabi. Salafism is nothing but the desire to, in a way, return to the origins of Islam. I know it is very difficult, but if we can do anything, always peacefully and democratically, of course, we will. (Fatima, Chile)

It was recently that I discovered what being Salafi means. In some Muslim chats, when you practice Islam and try to do things the best you can, I see that some people say, somewhat pejoratively, "that is salafi" or salafist, like, "that person is a radical, it's no use." Nothing is further from reality. I understand Salafism as following the Din, the path of Allah, as strictly as possible. (Melika, United Kingdom)

\section{Conclusion}

The women under study are not representative of all Niqabi women, since there are several Arab countries where women are constrained to 'opt' for the niqab. For example, in Saudi Arabia they are constrained to wear clothes similar to the niqab, something they call abaya. This collective declares to have freely and voluntarily chosen to be Niqabi-with all shades that may be given to that when talking about liberties. In this regard it's worth mentioning that their discourses take place in a western, modern context. They live in countries that have undergone intense secularization processes even though their political positions and regimes are very different. Moreover, we guess and propose as hypothesis for future research that there are differences between Niqabi women living in western countries and whose identity is constructed using the Internet, and those who do not have access to the Internet or whose use of the niqab is not motivated by a religious norm.

With that said, as we have seen, Niqabi women belonging to the virtual community Orgullo Niqabi in Telegram interpret the world in a fundamentalist way. Paradoxically, even though these women demand a return to the origins, to a considerably idealized past based on religious parameters, they use some emerging, modern tools as an identity, social and even political claim. That is, in a way, these women are modern, but not modernist. We can say that, when the interviews were conducted, these women were in the dawning of giving birth to a possible social movement grounded on a pacific reaction to modernity. Some theorists argue that these types of reaction brought together under any kind of social movement derive from economy globalization, while others consider that they derive from the crisis of the traditional family model. Some others maintain that contemporary societies are always in the frontier between social change and individual mobility, and that is the reason why we are bound to periodically doubt of the benefits of modernity and secularization and to yearn for the safety of traditional institutions and values. It is clear, however, that this group of women has found in Telegram the locus of enunciation they needed to express themselves and where they can deliberate freely, without having to be represented by an intermediary unconnected to their collective (Spivak, 1999).

Far from victimhood, this community presents itself as an agent for social change. These women reformulate a situation that they perceive discriminatory and grounded on prejudices and stereotypes, and they find their own mechanisms and a space where they can fight and articulate their demands, especially those concerning their identity. They carry out this through the elaboration of a manifesto which we do not know whether it is already finished or not but, in any case, it has not been published yet. At the same time, they plan their expansionist project away from any watchful eye which might condition their demands. All of this is carried out in the 
non-space, the corner that Telegram is for them, legally coexisting in our societies but on the fringes of legality and its legitimate mechanisms of vigilance (conventional or not). That would be another subject worth discussing but, without getting into moral or ethic debate, said vigilance might come from the perception that the different security corps have: They see the potential for fundamentalism to evolve to fundamentalist terrorism, something that has already happened in the past. According to Beriain (2011), one of the problems of nihilist fundamentalism is not expressing difference, which is something inalienable in modern thinking, but to impose it with blood. This author uses an interesting concept: nihilism. It may be linked to the answer to why these women react that way to the very essence of modernity: laicism and, more precisely, secularization. This is a key subject since it poses several questions: are our societies ready to give room to these forms of living a religion? Should these new forms of living a religion adapt, in the literal sense of the term, to the secular essence of our societies? On the contrary, should social spaces be deconstructed as to give room to new scenarios? If that was to be the case, the illustrious pillars that are so rooted in the very essence of our status quo would be dynamited giving rise to a new scenario, so unlikely that it would be unthinkable today: Could we humorously talk about the democracy of fundamentalism? But if that was not to be the case, these forms of living religion would stay as they currently are, that is, relegated to the sphere of secrecy, non-recognition and non-space, always being watched with distrust, as a potential threat. Are we unconsciously fueling a situation where groups of a pacific nature become violent? When the project of forming individuals that participate of modernity is seen as something absurd in daily routine-who can imagine a Niqabi woman teaching at a school or as cashier at a supermarket nowadays? - then violence becomes, very frequently, the only way of self-affirmation.

\section{Acknowledgments}

We wish to thank all the women that have participated in this research and agreed to be interviewed. We also thank all of those that, even willing to participate, were left out of the study due to various reasons out of their control.

\section{Conflict of Interests}

The authors declare no conflict of interests.

\section{References}

Ainz, A. (2011). La percepción de las mujeres veladas sobre su inserción en el mercado laboral español: Un estudio longitudinal [The perception of veil-wearing women about their inclusion in the Spanish labor market: A longitudinal study]. Cuadernos Intercultur- ales, 9(17), 187-198.

Ainz, A. (2017). Mi yo fundamentalista [My fundamentalist self]. Madrid: Circulo rojo.

Ainz, A. (2018). Una aproximación al estudio del discurso de las mujeres niqabi en España [An approach to the study of the discourse of Niqabi women in Spain]. Revista del Instituto Español de Estudios Estratégicos, 11, 153-170.

Ainz, A., Checa, J. C., \& González, M. J. (2011). Redes sociales y religión. El caso del grupo "islam en español” en facebook [Social networks and religion. The case of the group "Islam in Spanish" on Facebook]. Prisma Social, 2011(6), 1-25.

Anderson, B. (2006). Imagined communities: Reflections on the origin and spread of nationalism. London and New York, NY: Verso.

Bauman, Z. (2007). Miedo líquido. La sociedad contemporánea y sus temores [Liquid fear. Contemporary society and its fears]. Barcelona: Paidós

Beriain, J. (2011). El sujeto transgresor y transgredido [The transgressor and the transgressed subject]. Barcelona: Anthropos.

Carrero, V., Soriano, R. M., \& Trinidad, A. (2012). Teoría fundamentada: El desarrollo de la teoría desde la generalización conceptual [Grounded Theory: The development of a theory from conceptual generalization]. Madrid: Centro de Investigaciones Sociológicas.

Castells, M. (2008). La era de la información: Economía, sociedad y cultura. Volumen I: La sociedad red [The age of information: Economy, society, and culture. Volume I: The network society]. Madrid: Alianza Editorial.

Castells, M. (2009). Comunicación y poder [Communication and power]. Madrid: Alianza Editorial.

Charmaz, K. (1990). "Discovering" chronic illness: Using Grounded Theory. Social Science and Medicine, 30(11), 1161-1172.

Cuff, E. C., Sharrock, W. W., \& Francis, D. W. (1990). Perspectives in sociology. London: Unwin Imán.

Downey, J., \& Fenton, N. (2003). New media, counter publicity and the public sphere. New Media and Society, 5(2). https://doi.org/10.1177\%2F1461444 803005002003

Fraser, N. (1997). Transnationalizing the public sphere: On the legitimacy and efficacy of public opinion in a post-Westphalian world. Theory, Culture \& Society, 24(4), 7-30.

Glaser, B., \& Strauss, A. (1967). The discovery of Grounded Theory: Strategies for qualitative research. New York, NY: Aldine Publishing.

McLuhan, M., \& Barrington, N. (1972). Take today: The executive as dropout. New York, NY: Harcourt Brace Jovanovich.

Olmeda, A. (2014). La democracia del siglo XXI. Política, medios de comunicación, internet y redes sociales [21st century democracy. Politics, mass media, internet and social networks]. Madrid: Centro de Estudios Políticos y Constitucionales. 
Pace, E., \& Guolo, R. (2006). Los fundamentalismos [Fundamentalist movements]. Mexico: Siglo XXI.

Rheingold, H. (2004). Multitudes inteligentes: La próxima Revolución Social [Smart mobs: The next social revolution]. Barcelona: Gedisa.

Ritzer, G. (1993). Teoría Sociológica Contemporánea [Contemporary sociological theory]. Madrid: Macgraw-Hill.

Roy, O. (1992). L'Échec de I'Islam politique [The success of political Islam]. Paris: Éditions du Seuil.

Roy, O. (2010). La santa ignorancia [Holy ignorance: When religion and culture part ways]. Madrid: Atalaya.
Spivak. G. (1999). A critique of postcolonial reason: Towards a history of the vanishing present. Cambridge, MA: Harvard University Press.

Tang, L., \& Yang, P. (2011). Symbolic power and the Internet: The power of a 'horse.' Media, Culture and Society, 33. https://doi.org/10.1177\%2F016344 3711404462

Thompson, J. (2005). La nueva visibilidad [The new visibility]. Papers, 78, 11-29.

Toffler, A. (1980). La tercera ola [The third wave]. Bogotá: Plaza \& Janes.

Žižek, S. (2003). The puppet and the dwarf: The perverse core of Christianity. Cambridge, MA: MIT Press.

\section{About the Authors}

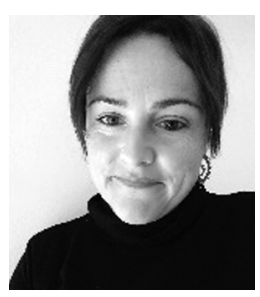

Alexandra Ainz-Galende, born in 1981 in the Basque Country (Spain), studied Sociology at the University of the Basque Country. Alexandra is a Doctorate in Almería and, since 2007, Professor of Sociology at the University of Almería. Her research interests include migration, fundamentalism, and fundamentalist terrorism.

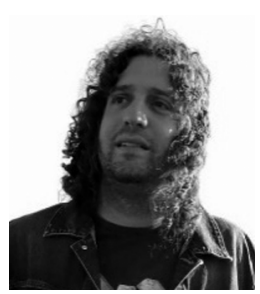

Rubén Rodríguez-Puertas is a Professor of Sociology at the Department of Geography, History and Humanities, University of Almería. His major lines of research are international migrations, globalization, youth, and labor market, with special focus on the current migration processes of young qualified people. 